\title{
Environmental variables vis-a-vis distribution of herbaceous tracheophytes on northern sub-slopes in Western Himalayan ecotone
}

\author{
Shevita Pandita ${ }^{1 *}$, Vinod Kumar ${ }^{2,3}$ and Harish Chander Dutt ${ }^{*}$
}

\begin{abstract}
Background: In the northern hemisphere, the north face of the mountains has a high diversity of species which is attributed to the moist and shady conditions at the north face. Other environmental variables may also influence the species diversity on the northern faces of the mountain and therefore needs to be studied in detail. The northern slopes represent three different sub-slopes_-north, north east, and north west. During the current investigation of PirPanjal and Dauladhar ranges in Bhadarwah valley, fine-scale studies on the relationship between vegetation and four variables (soil pH, moisture content, electrical conductivity, and steepness) were conducted. The study determined the role of these variables on the vegetation of three different sub-slopes. The sampling was done at the confluence of two communities (forest and grassland) at three sites on the northern sub-slopes of the lesser stratum in western Himalayan.
\end{abstract}

Results: The result revealed that rich herbaceous diversity prevails on the lesser Himalayan stratum (Bhadarwah valley). As many as $65.8 \%$ species differ from site to site, whereas species commonality among the sites is minimum. The role of environmental variables on the species composition at different sub-slopes of the north mountain face is deduced through canonical correspondence analysis (CCA).

Conclusions: The availability of solar light increases air and soil temperature on the north east-facing slope. All the environmental variables (soil pH, moisture, electrical conductivity, and mountain steepness) are insignificant at pure north face for the species composition. Therefore, it can be concluded that some other environmental variables may influence the species composition which are needed to be further investigated.

Keywords: North face, Environmental variables, Species heterogeneity, Treeline ecotone, Species turnover, Canonical correspondence analysis

\section{Introduction}

The particular mountain face composes a unique habitat for a specific type of plant community (Nowak et al. 2014). Each mountain face shows contrasting characteristics with respect to insolation, light intensity, soil moisture, $\mathrm{pH}$ of the soil, humidity, etc. (Pook and Moore 1966; Gupta and Arora 2017). These facets are also closely associated with the vegetation composition and community

\footnotetext{
*Correspondence: pandita.shweta@rediffmail.com; hcdutt@rediffmail.com ${ }^{1}$ Department of Botany, University of Jammu, Jammu, Jammu and Kashmir 180006, India

Full list of author information is available at the end of the article
}

structure (Gilliam et al. 2014; Kumar et al. 2018). The north-facing slopes retain moisture and are more cold and humid than the south-facing slopes; consequently, they support moisture-loving plants (Erdos et al. 2012). The north slopes offer a better habitat for plant growth and help in adequate regeneration of species (Maren et al. 2015). The north-facing slopes are characterized by higher species diversity than the south-facing slope (Gong et al. 2008; Ucles et al. 2015). These slopes are efficient ecosystems for maintaining a specific microhabitat (Mehrabi et al. 2014). The microhabitat parameters (soil pH, moisture, electrical conductivity, etc.) influence the species 
richness/heterogeneity on the north-facing slopes (Härdtle et al. 2003; Maren et al. 2015).

Ecosystem being a cybernetic system maintains a specific species composition and richness using various environmental variables (Odland and Birks 1999). Among various environmental variables, altitudinal and latitudinal gradients also contribute to the maintenance of species diversity (Murray 1997; Bhattarai 2017). In this regard, the altitudinal gradients along with geographical coordinates are evaluated for their pivotal role in the distribution of vegetation (Juarez et al. 2007; Kazakis et al. 2007). In recent years, new approaches to quantify changes in species diversity across environmental gradients and boundary regions are also developed (Wilson and Shmida 1984; Koleff et al. 2003; Mena and Domi'nguez 2005). Beta-diversity or species turnover is recognized as a simple modus operandi for comparing the diversity of two landscapes or communities or ecosystems (Wilson and Shmida 1984).

Transition zone also called ecotone has become a central topic in landscape ecology and nature conservation because of high floral and faunal diversity. Therefore, the study of ecotone is one of the most rampant research fields nowadays (Cadenass et al. 2003; Ries et al. 2004; Yarrow and Marin 2007, Erdos et al. 2014). Apart from maximum biodiversity, transition zones are differentiated from their nearby communities because these zones are known for maximum transfer of materials, energy, genotypes, and other environmental variables (Austin 2005; Kumar et al. 2017; Guerin et al. 2019). Ecotone delimits the spatial heterogeneity of a landscape and forms an ideal ecosystem (Fagan et al. 2003; Hou and Walz 2016).

Indian Himalayan Region (IHR), including the Tibetan Plateau, is a unique physico-geographical region with an average elevation of $4000 \mathrm{~m}$ above msl (Zheng et al. 1981; Ding et al. 2014). The western Himalayan montane and subalpine vegetation on north slopes primarily consist of coniferous species comprising stands of Abies pindrow (Royle ex D. Don) Royle, Pinus wallichiana A. B. Jacks., Picea smithiana (Wall.) Boiss., and Cedrus deodara (Roxb. ex D. Don) G. Don). At few places, individuals of birch (Betula utilis D. Don) also grow in the upper subalpine belt. These individuals of birch finally turn into a narrow band of more or less pure birch stands (Schickhoff et al. 2015). These stands are followed by the grasslands and pastures at high elevation at various mountain faces. Out of the four major mountain faces (north $(\mathrm{N})$, south $(\mathrm{S})$, east $(\mathrm{E})$, and west $(\mathrm{W})$ ), north face is not always known for high densities of mesic temperate species and south face predominate by paleotropical xeric biota (Erdos et al. 2012; Nevo 2001). Moreover, the north and east faces of the mountains are evaluated as more productive slopes (Maren et al. 2015). Therefore, the number of studies on vertical transects has been conducted to understand the ecology and species distribution.

Along the elevational gradient (vertical transect), species richness may decrease with the increase in altitudes on the north face (Grytnes 2003). However, such studies on horizontal plane for sub-slopes of the north face like pure $\mathrm{N}$, north east (NE), and north west (NW) are wanted in the science. Moreover, the role of environmental variables on vegetation at specific sub-face of the north is also not fully tacited by the ecologists. During the current study, sampling sites were selected on the transition zone between forest-grassland communities, because of structural composition and functional value of these ecosystems. Data has been collected to understand the role of environmental variables on herbaceous species diversity at various sub-slopes of the north.

\section{Material and methods \\ Study area}

Himalaya, divisible in three zones (a) Outer, (b) Lesser, and (c) Greater Himalaya, is a unique mountain system with respect to climate, rainfall, soil, topography, etc. Lesser Himalaya is a middle stratum extended from eastern to western Himalaya in ca. $2000 \mathrm{~km}$ between Shiwalik Range in the south and Great Himalaya in the north. It is composed of many important temperate ranges like Pir-Panjal, Dauladhar, etc. in western Himalaya. Each range possesses gentle northern and steep southern slopes. Northern slopes of Lesser Himalaya are characterized with thick tree flora ranging from boardleaved species to conifers in western Himalaya. In addition, high altitudes also hold a rich herbaceous species diversity forming grassland ecosystems. The study is conducted in Bhadarwah valley falling in Lesser Himalaya which is located in the north western portion of IHR (Fig. 1). The study area lies between an altitudinal range from 821 to $4400 \mathrm{~m}$ above msl on geographical coordinates 33.081' $\mathrm{N}$ and 75.332' $\mathrm{E}$ to 32.514' $\mathrm{N}$ and 75.412' $\mathrm{E}$ (Dutt and Kant 2007). This part of the Himalaya holds a variety of vegetation ranging from sub-tropical to alpine. The area is dominated by coniferous forests from 1200 to $3300 \mathrm{~m}$ above msl followed by grassland ecosystems which supports more than 194 medicinal plants (Chander 2005). A total of 488 species belonging to 323 genera represent the flora of the study area. Climatic parameters like annual temperature, relative humidity, and other ombrothermic features are responsible for the predominance of family Asteraceae in Bhadarwah (Kumar 1987). Phytoclimate of the area is thero-hemicryptophytic because of many ecological factors at macro-, meso-, and microclimatic level (Kumar 1987; Chander 2005).

\section{Arrangement of plots and sampling}

To cover all the possible three sub-slopes (NW, NE, and $\mathrm{N}$ ) of the northern mountain face, 4 sites (1 site in NW, 


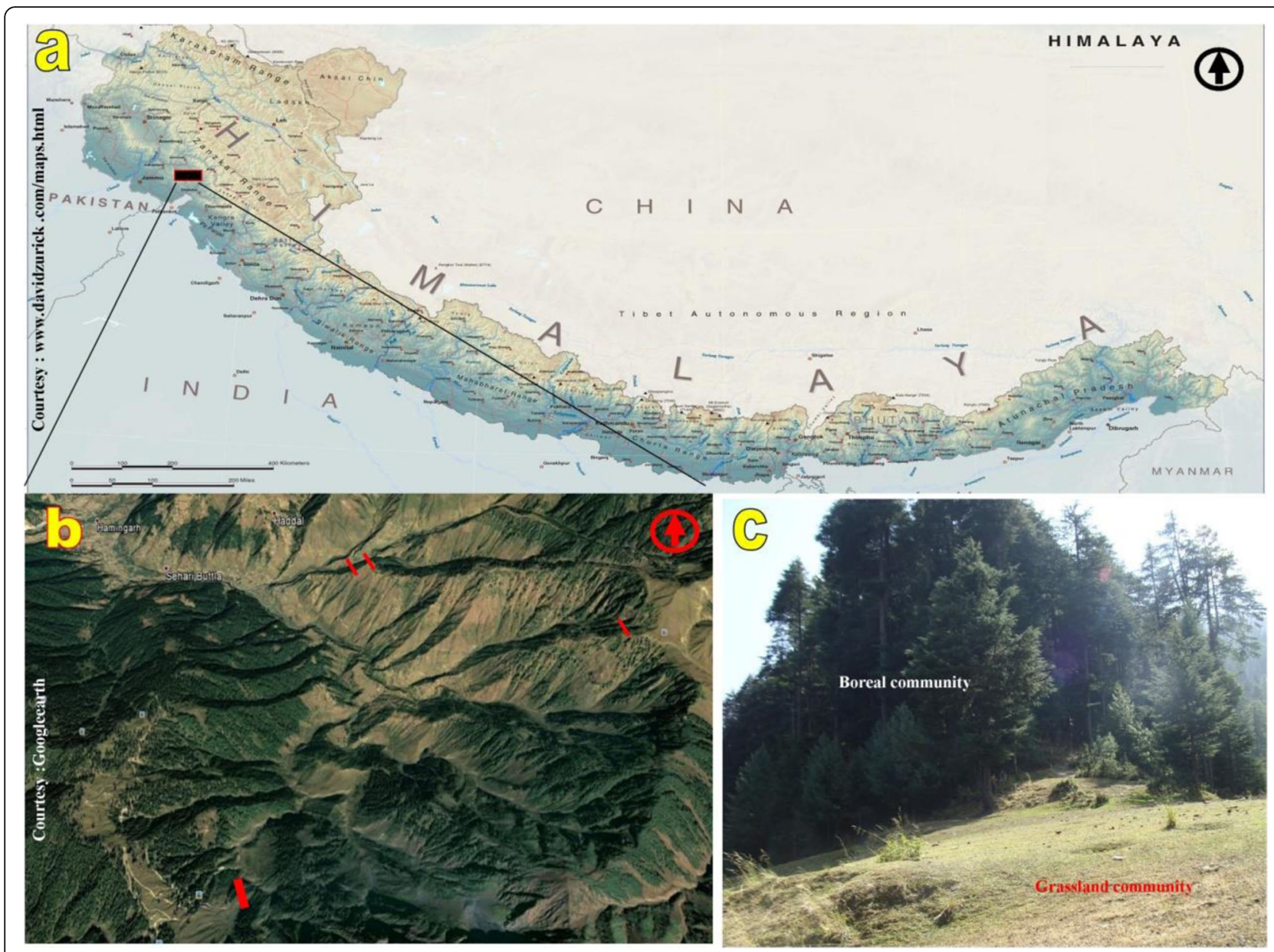

Fig. 1 Study area showing coniferous forest and grassland communities in the lesser stratum of NW Himalaya. a Himalaya mountain system. b Sampling sites (red strips) in the lesser stratum of in NW Himalaya. c A study site showing forest and grassland communities along the altitude gradient in the lesser stratum of NW Himalaya. Source: www.davidzurick.com/maps.html. Red color strips in $\mathbf{b}$ indicate the location of sampling sites

1 site in NE, 2 sites in $\mathrm{N}$ ) at different mountain peaks were identified for the study. The details of the sites are presented in Table 1. Each site was identified at the confluence of forest and grassland communities because such transition zone possesses maximum species diversity. Northern face was selected purposely because this face is always earmarked with wet and shady conditions responsible for high species richness. One hundred continuous sampling units of $1 \mathrm{~m}^{2}$ were laid down along each long transect (100 units $\times 4$ sites) (Fig. 2). Each transect was arranged from the interior of the forest to the interior of the grassland communities intersecting ecotone in perpendicular (Pandita and Dutt 2016). Semirandom sampling procedure was adopted to select the site considering forest communities at low and grassland communities at high elevation. Semi-random sampling is a modified form of stratified sampling. In the stratified random sampling method, the study site was divided into a number of homogenous units, and then samples in these units are placed randomly. Evidently, in this approach, all variations in vegetation considered as samples are distributed throughout the area. This method

Table 1 Details of study sites in Lesser Himalayan stratum

\begin{tabular}{llllll}
\hline S. No. & Study sites & Mountain aspect & Geographical coordinates & Elevation (meters above msl) & Herbaceous species \\
\hline I & KHA & North (N) & $32^{\circ} 56.282^{\prime}$ N-75 $46.109^{\prime} \mathrm{E}$ & 2266 & 26 \\
II & BP & North west (NW) & $32^{\circ} 55.269^{\prime} \mathrm{N}-75^{\circ} 47.416^{\prime} \mathrm{E}$ & 2784 & 33 \\
III & GUL & North east (NE) & $32^{\circ} 54.008^{\prime} \mathrm{N}-75^{\circ} 45.184^{\prime} \mathrm{E}$ & 2916 & 42 \\
IV & BRK & North (N) & $32^{\circ} 56.326^{\prime} \mathrm{N}-75^{\circ} 45.878^{\prime} \mathrm{E}$ & 2142 & 28
\end{tabular}

KHA, Khanitop; BP, Below Padhri; GUL, Guldanada; BRK, Budh Ro Kut 

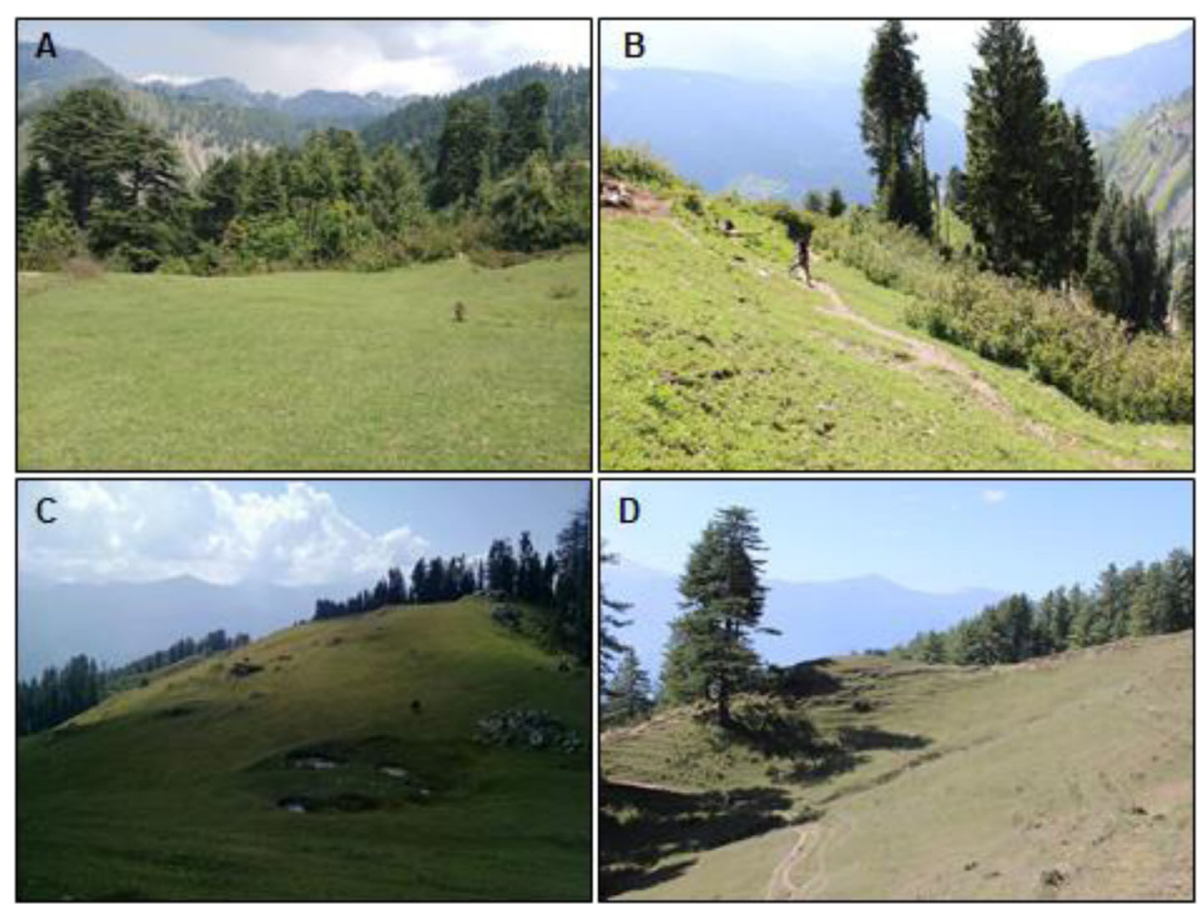

Fig. 2 Sampling sites location. a Khanitop. b Below Padhri. c Guldanada. d Budh Ro Kut

combines advantages of both systematic and random sampling (namely accuracy and statistical validity respectively) (Singh et al. 2010). Data on the herbaceous tracheophytes, their individuals, and other environmental variables were recorded in the peak season of vegetation (June to August 2016). The species were collected and identified using various field guides and taxonomic keys published in local floras (Polunin and Stainton 1984; Sharma and Kachroo 1983). The collected specimens were transformed into herbarium sheets according to published guidelines (Dutt and Bedi 2014).

\section{Environmental variables}

Data for 4 environmental variables namely, $\mathrm{pH}$, electrical conductivity (EC), moisture contents of soil (SM), and steepness in the mountain slope (MS) were collected in situ using portable $\mathrm{pH}$ meter (EuTech), field conductivity meter (ME Max digital conductivity meter), soil moisture meter (ELICO DM-33), and inclinometer (BOSCH DNM 60 L), respectively. The reason for in situ analysis was longer sampling durations, and in order to maintain the accuracy of parameters the analysis was done under in situ conditions.

\section{Statistical analysis}

Data on environmental variables and individuals of plant species were arranged on Microsoft Excel. Correct names of the species were authenticated using a webbased database (www.theplantlist.org) and taken as the biotic parameter. Canonical correspondence analysis (CCA) is a multivariate method to elucidate the relationships between biological assemblages of species and their environmental variables (Hejcmanovā-Nežerková and Hejcman 2006). The CCA was performed using PAST v. 3.21 software.

\section{Results}

\section{Characteristics of the study area}

During the current study, ecotone between forest and grassland communities on northern slopes between PirPanjal and Dauladhar ranges is explored (Table 1). The data collection reveals that ca. 84 herbaceous species exist in such regions in the Lesser Himalayan part of western Himalaya (Additional file 1: Table S1). Out of 84 species encountered during the study, ca. $5.8 \%$ species are recorded common among 3/4 sites; however, ca. $65.8 \%$ species differ from site to site (Fig. 3). The species-area curve helped in the demarcation of three communities namely forest, ecotone, and grassland along each transect.

\section{Environmental variables}

Substratum is the outcome of interactions of various environmental variables. During the current study, $\mathrm{pH}$ was found to be slightly acidic to near alkaline, whereas $\mathrm{pH}$, moisture content, EC, and steepness of the mountain in forest soil range from 6.1 to $6.7,35$ to $39 \%, 0.008$ to 0.016 simens $/ \mathrm{m}$, and 63 to 82.7 degree of angle, 


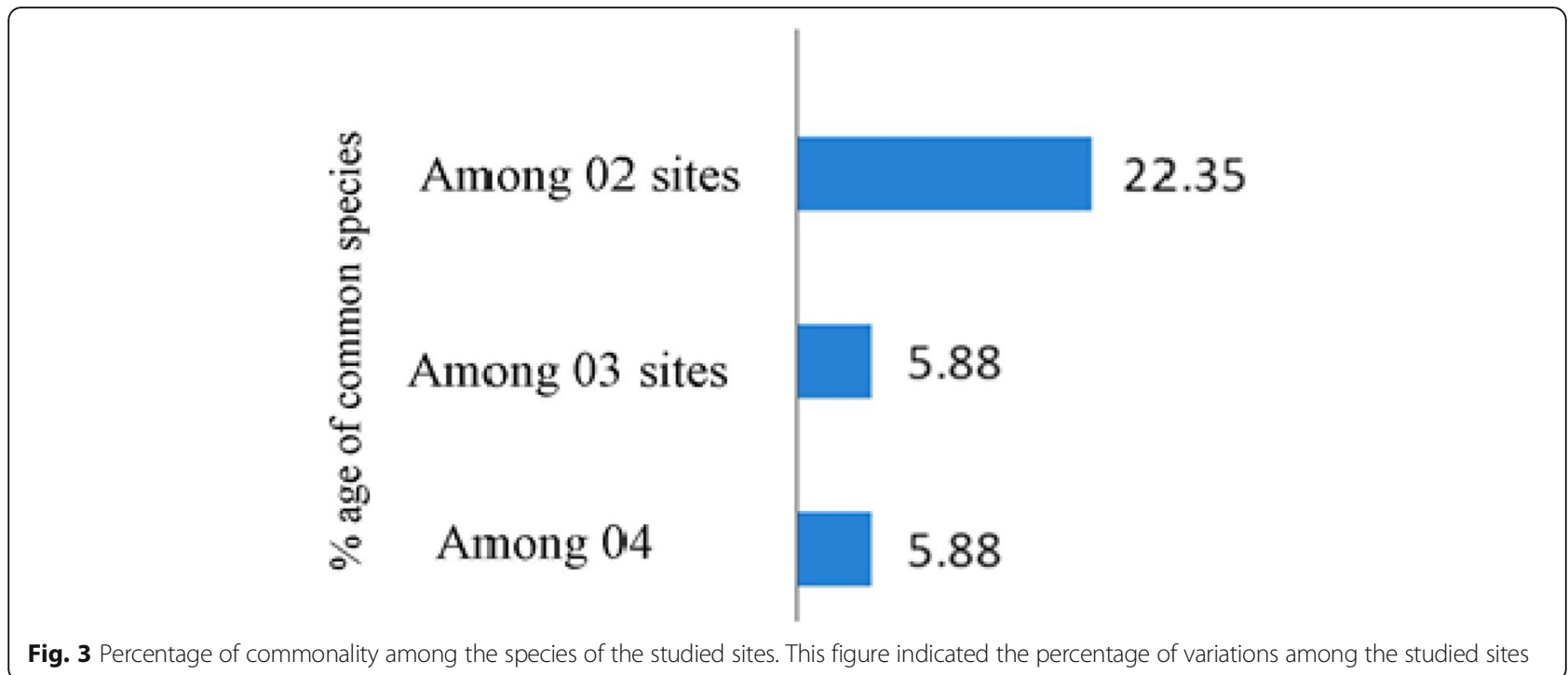

respectively. Similarly, $\mathrm{pH}, \mathrm{SM}, \mathrm{EC}$, and MS in transition zone range from 6.4 to $6.7,33$ to $35 \%, 0.18$ to 0.135 simens $/ \mathrm{m}$, and 60 to 80.2 degree of angle, respectively. In grassland soil, $\mathrm{pH}, \mathrm{SM}, \mathrm{EC}$, and MS range from 6.9 to $7.5,15$ to $20.5 \%, 0.036$ to 0.071 simens $/ \mathrm{m}$, and 18 to 78.6 degree of angle, respectively (Table 2). Although on the northern hemisphere, north-facing slopes are recognized as rich in biodiversity, but this species richness decreases with an increase in the altitudes (Grytnes 2003). In our study, we tried to investigate the relationship between four environmental variables with species diversity at three sub-slopes of the north face. Data analysis reveals that the NE and NW faces are rich in terms of the herbaceous tracheophytes than pure north sub-slopes (Table 1). pH, SM, EC, and MS also differ on each sub-slopes (N, NE, and NW) as well as on each community (forest, ecotone, and grassland) (Table 2).

\section{Relationship of environmental variables and biological assemblage}

The results of the CCA are presented in Fig. 4, where lines represent the soil properties and small circle represents the tracheophytes. Forest cover is characterized by stands of coniferous species predominated by Cedrus deodara (Roxb. ex D. Don) G. Don trees. Other tree species like Picea smithiana (Wall.) Boiss., Abies pindrow (Royle ex D.Don) Royle, and Pinus wallichiana A.B. Jacks co-dominate the tree vegetation in the study area. Berberis lycium Royle, Viburnum grandiflorum Wall. ex

Table 2 Environmental variables at different sites among three communities

\begin{tabular}{|c|c|c|c|c|c|}
\hline $\begin{array}{l}\text { Site } \\
\text { communities }\end{array}$ & & $\begin{array}{l}\mathrm{pH} \\
\text { of the soil }\end{array}$ & $\begin{array}{l}\text { Moisture } \\
\text { contents of soil } \\
\text { (in \%) }\end{array}$ & $\begin{array}{l}\text { Electrical } \\
\text { conductivity of soil } \\
\text { (in simens } / \mathrm{m} \text { ) }\end{array}$ & $\begin{array}{l}\text { Steepness } \\
\text { of the } \\
\text { mountain } \\
\text { (in angle) }\end{array}$ \\
\hline \multirow[t]{3}{*}{ I } & $\mathrm{F}$ & 6.1 & 36.5 & 0.016 & 63 \\
\hline & E & 6.7 & 33 & 0.024 & 60 \\
\hline & G & 7.4 & 15 & 0.036 & 18 \\
\hline \multirow[t]{3}{*}{$\|$} & $\mathrm{F}$ & 6.4 & 39 & 0.015 & 79 \\
\hline & E & 6.4 & 35 & 0.018 & 80.2 \\
\hline & G & 7.2 & 16 & 0.04 & 78.6 \\
\hline \multirow[t]{3}{*}{ III } & $\mathrm{F}$ & 6.5 & 37 & 0.008 & 78 \\
\hline & E & 6.6 & 33 & 0.135 & 62.2 \\
\hline & G & 7.5 & 15.5 & 0.038 & 48 \\
\hline \multirow[t]{3}{*}{ IV } & $\mathrm{F}$ & 6.4 & 35 & 0.046 & 6.9 \\
\hline & $\mathrm{E}$ & 6.7 & 34 & 0.053 & 20.5 \\
\hline & $\mathrm{G}$ & 6.9 & 20.5 & 72 & 47.2 \\
\hline
\end{tabular}




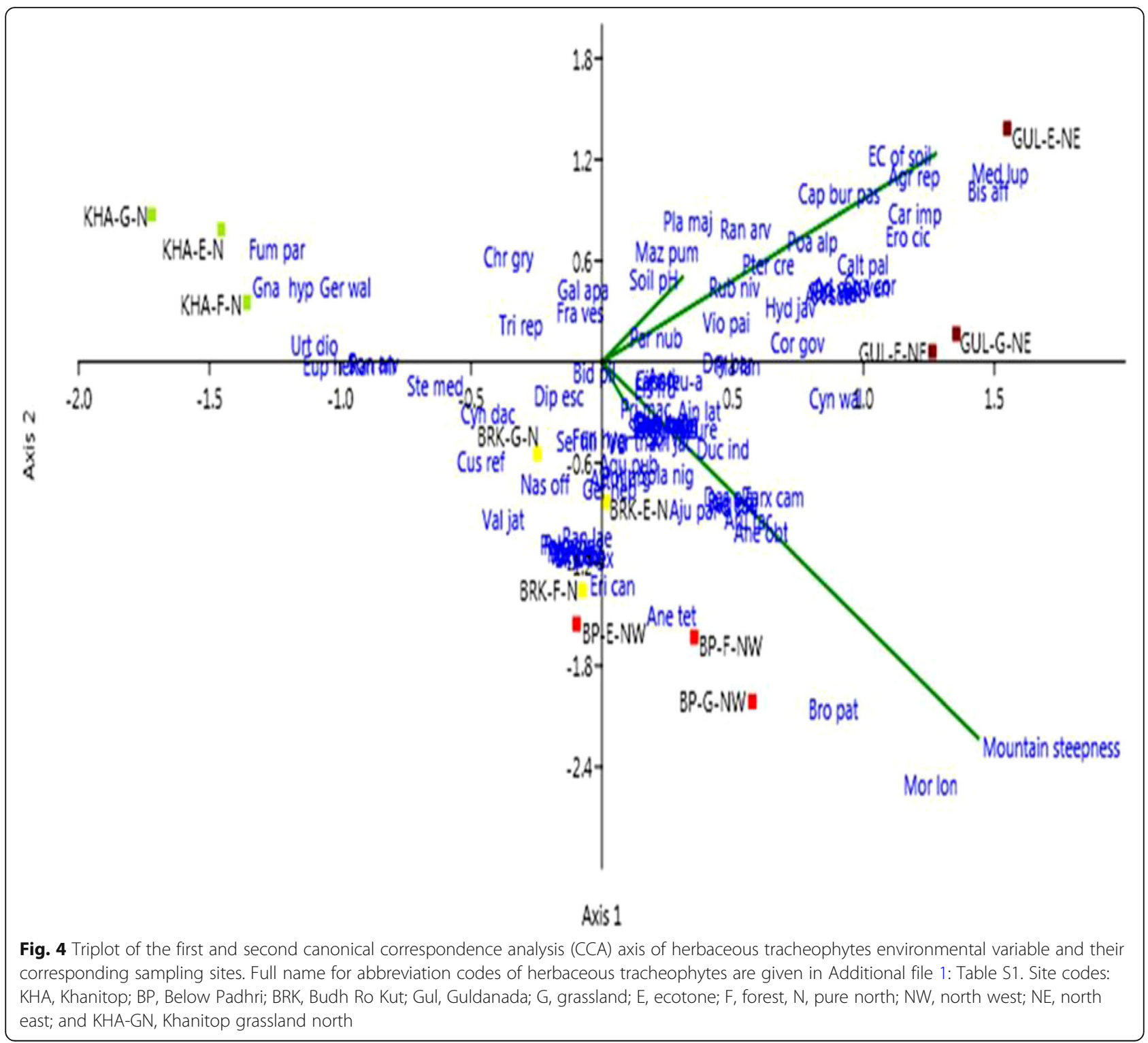

DC., Quercus baloot Griff., Rubus ellipticus Sm., Rosa webbiana Wall., and Prinsepia utilis Royle form the shrub layer in forest as well as at transition zone between forest and grassland. CCA map reveals that the studied environmental variables influence the herbaceous species at NE and NW mountain faces. Herbaceous tracheophytes like Morina longifolia Wall., Bromus patulus var. falconeri Stapf., Anemone tetrasepala Royle are the most significant species at NW face, and important environmental variables contributing maximum in setting the ecology at this face are MS and SM. However, Bistorta affinis Greene., Medicago lupulina L., Agropyron repens (L.) P. Beauv., and Cardamine impatiens L. are significant species on NE face. The most significant environmental variables at NE face are identified as $\mathrm{EC}$ and $\mathrm{pH}$ of the soil. At pure $\mathrm{N}$ face, species like Fumaria parviflora L., Gnaphalium hypoleucum DC., and Geranium wallichianum D. Don ex Sweet. are significant species (Fig. 4). CCA being a strong statistical tool helps to comprehend the role of soil $\mathrm{pH}, \mathrm{SM}$, soil EC, and MS on the biotic variable (density of herbaceous tracheophytes). CCA reveals that environmental variables like soil EC-pH and MS-SM have high degree of impact on the species composition at NE and NW sub-faces, respectively. CCA at 999 random permutations visualized simultaneously the biotic variables and the environmental variables at different mountain aspects on two axes (Fig. 4). Critical analysis on the CCA map indicates that the EC of the soil has more significant role than the $\mathrm{pH}$ of the soil on NE face. However, on the NW face, MS is recognized as a chief environmental variable than SM. Herbaceous tracheophytes are 
insensitive to any of the studied environmental variables on pure north face in Lesser Himalaya. Among herbaceous tracheophytes, few species are more significant on their specific site of occurrence.

\section{Discussion}

Both north and south slopes of Lesser Himalayan mountain abode coniferous forest at low and grassland communities at high altitudes. Behavior of the mountain's north face coupled with the environmental variables toward herbaceous tracheophytes has been elucidated by dividing the north slopes into three sub-slopes (pure north, north east, and north west). NE and NW faces are observed as the paramount habitat for the growth of herbaceous tracheophytes. Data collection on the number of species on vertical belt transects from forest to grassland communities intersecting perpendicularly transition zone helped in the identification of 3 communities namely forest, ecotone, and grassland. Presence or absence of individual species indicated that the transition zone is characterized by the maximum number of species and their individuals. Climate, topography, aspect, inclination of slope, soil type, and land use pattern are recognized as the major contributor to vegetation type (Maren et al. 2015). Furthermore, insolation and light intensity also put down a range of microclimates at the multifaceted landscape. These factors are responsible for the diverse type of vegetation at different mountain aspects (Gillingham 2010). Variation in vegetation between two contrasting aspects (mountain faces) is the result of the difference in reception of solar radiation (Ghimire et al. 2010; Paudel and Vetaas 2014). On the northern hemisphere, south-facing slopes receive more sunlight and become more xeric and warmer. Therefore, such slopes support drought-resistant vegetation and are less favorable for tree growth. However, north-facing slopes hold moisture and remain cold as well as humid, thus supporting moistureloving plants (Nevo 2001; Maren et al. 2015). It has also been implicated that south-facing slopes receive six times higher solar radiation than north-facing slopes. Therefore, the microclimatic conditions on both slopes differ considerably and uphold different levels of biodiversity (Auslander et al. 2003). Ecotones are described as dynamic zones and play several important roles in ecosystem functioning (Pandita and Dutt 2016). Himalayan treeline ecotones show considerable differences in altitudinal position, physiognomy, and species composition (Schickhoff 2005). Detection of ecotones can be done using field data gathered along transects (one dimension) or across a grid (two dimensions). During the current study, data collection on one dimension reveals that the species composition at ecotone varies drastically from site to site. This indicates that beside species interaction other factors also play imperative role in ecotones. Few species act as ecotonal specialists; therefore, the strongest process for species richness in Lesser Himalaya can be additive blending. Additive blending may be because of an intermediate type of microhabitat with respect to $\mathrm{pH}$, moisture content, EC, and steepness of the mountain at ecotone (Table 2).

Out of studied communities, ecotone is a well-studied community because of its unique characteristic features (Erdos et al. 2012). Mohd-Aizat et al. (2014) while working on soils of Ayer Hitam Forest Reserve reported a pH range of 3.12 to 5.28 which is lower compared with the present work. Ashraf et al. (2012) reported a range of pH 5.90 to 6.23 , moisture content 13.3 to $19.3 \%$, and EC 207 to $239 \mu \mathrm{S} / \mathrm{cm}$ in grassland soils of Yusmarg Hill Resort. Fauze et al. (2015) in their confirmation on soils of Yamuna Biodiversity Park, Delhi, found that $\mathrm{pH}$ varied from 6.82 to 7.90 ; EC, 96 to $1679 \mu \mathrm{S} / \mathrm{cm}$; and moisture content, 8.7 to $29.7 \%$, and corroborate with the current findings.

\section{Conclusions}

The present work showed that species have very less similarity (ca. 6\%) among different sites, indicating that each mountainous habitat is characterized by high species diversity at a coarse scale. EC-pH of the soil on NE-facing slopes and SM-MS are vital variables on NW-facing slopes. The insolation and period of solar energy are also dependent on the position of the slope. The north east slopes receive maximum insolation, since the studied area is placed on the northern hemisphere. The availability of solar light increases air and soil temperature on the north east-facing slope. All the environmental variables (soil pH, moisture, $\mathrm{EC}$, and mountain steepness) are insignificant at pure north face for the species composition. Therefore, it can be concluded that some other environmental variables may influence the species composition which are needed to be further discovered.

\section{Supplementary information}

Supplementary information accompanies this paper at https://doi.org/10. 1186/s13717-019-0200-x.

Additional file 1: Table S1. Herbaceous species encountered in all the transects at study sites. The data collection reveals that ca. 84 herbaceous species exist in such regions in Lesser Himalayan part of western Himalaya.

\section{Abbreviations}

BP: Below Padhri; BRK: Budh Ro Kut; CCA: Canonical correspondence analysis; E: Ecotone; EC: Electrical conductivity; F: Forest; G: Grassland; Gul: Guldanada; KHA: Khanitop; KHA-GN: Khanitop grassland north; MS: Steepness of the mountain; N: Pure north; NE: North east; NW: North west; SM: Soil moisture content

\section{Acknowledgements}

The authors are thankful to Head, Department of Botany, University of Jammu, Jammu, for providing the herbarium and other equipment facilities 
to conduct the study. Authors are also thankful to Prof. Rahul Gupta, Department of Statistics, University of Jammu, Jammu, for helping in the application of statistical tool during the study. A trial version of StyleWriter 4 is also acknowledged for punctuation and English language proofreading.

\section{Authors' contributions}

SP and HCD designed and analyzed the samples. SP wrote the initial draft of the paper. VK and HCD help in finalizing the paper. All authors read and approved the final manuscript.

\section{Funding}

Not applicable.

\section{Availability of data and materials}

Not applicable.

\section{Ethics approval and consent to participate}

Not applicable.

\section{Consent for publication}

Not applicable.

\section{Competing interests}

The authors declare that they have no competing interests.

\section{Author details}

'Department of Botany, University of Jammu, Jammu, Jammu and Kashmir 180006, India. ${ }^{2}$ Department of Botany, DAV University, Jalandhar 144012, India. ${ }^{3}$ Assistant Professor, Department of Botany, Govt College for women Gandhi Nagar, Jammu 180003, India.

\section{Received: 8 July 2019 Accepted: 29 October 2019}

Published online: 27 November 2019

\section{References}

Ashraf M, Bhat GA, Dar IY, Ali M (2012) Physico-chemical characteristics of the grassland soils of Yusmarg Hill Resort (Kashmir, India). Ecologia Balkanica 4(1): $31-38$

Auslander M, Nevo E, Inbar M (2003) The effects of slope orientation on plant growth development instability and susceptibility to herbivores. J Arid Environ 55:405-416

Austin MP (2005) Vegetation and environmental: discontinuities and continuities. In: der Maarel V (ed) Vegetation ecology. Blackwell, Oxford, pp 52-84

Bhattarai KR (2017) Variation of plant species richness at different spatial scales. Bot Orient J Plant Sci 11:49-62

Cadenass ML, Pickett STA, Weathers KC, Bell SS, Benning TT, Carreiro MM, Dawson TE (2003) An interdisciplinary and synthetic approach to ecological boundaries. Bioscience 53:717-722

Chander H (2005) Ecological studies and conservation of medicinal plants of Neeru watershed. PhD Thesis, University of Jammu, Jammu, India

Ding L, Xu Q, Yue Y, Wang H, Cai F, Li S (2014) The Andean-type Gangdese Mountains: paleoelevation record from the Paleocene-Eocene Linzhou Basin. Earth Planet Sci Lett 392:250-264

Dutt HC, Bedi YS (2014) Problems associated with studying spatial distribution of plants through herbarium anthology: a case study of family Berberidaceae in north west Himalaya. Proc Natl Acad Sci India Sect B 84:465-471

Dutt HC, Kant S (2007) Forest types of Neeru valley Bhadarwah Jammu and Kashmir. In: Kumar A, Nehar S (eds) Environmental protection. Daya Publishing House, New Delhi, pp 284-289

Erdos L, Meri A, Batori Z, Galle R, Kormoczi L (2012) North-south facing vegetation gradients in the Villainy Mts: a case study on the population and the community level. Pak J Bot 44:927-932

Erdos L, Zalatnai M, Batori Z, Kormoczi L (2014) Transitions between community complexes: a case study analyzing gradients through mountain ridges in South Hungary. Acta Bot Croatica 73:63-77

Fagan WF, Fortin MJ, Soykan C (2003) Integrating edge detection and dynamic modeling in quantitative analyses of ecological boundaries. Bioscience 53: 730-738

Fauze AK, Khudsar FA, Sreenivasa (2015) Analysis of soil physico-chemical properties in various sites at Yamuna Biodiversity Park, Delhi, India. Int Innov Res Sci Eng Tech 4:7220-7228
Ghimire BK, Mainali KP, Chadhary RP, Ghimeray AK (2010) Regeneration of Pinus wallichiana $A B$ Jackson in a trans-Himalayan dry valley of north-central Nepal. Himal J Sci 6:19-26

Gilliam FS, Hédl R, Chudomelová M, McCulley RL, Nelson JA (2014) Variation in vegetation and microbial linkages with slope aspect in a montane temperate hardwood forest. Ecosphere 5(5):66

Gillingham P (2010) The relative importance of microclimate and land use to biodiversity. Doctoral dissertation. University of York, UK

Gong X, Brueck H, Giese KM, Zhang L, Sattelmacher B, Lin S (2008) Slope aspect has effects on productivity and species composition of hilly grassland in the Xilin river basin, Inner Mongolia, China. J Arid Environ 72:483-493

Grytnes JA (2003) Species-richness patterns of vascular plants along seven altitudinal transects in Norway. Ecography 26:291-300

Guerin GR, Andersen AN, Rossetto M, van Leeuwen S, Byrne M, Sparrow B, Lowe AJ (2019) Consistent sorting but contrasting transition zones in plant communities along bioclimatic gradients. Acta Oecol 95:74-85

Gupta RD, Arora S (2017) Characteristics of the soils of Ladakh region of Jammu and Kashmir. J Soil Water Conserv 16(3):260-266

Härdtle W, von Oheimb G, Westphal C (2003) The effects of light and soil conditions on the species richness of the ground vegetation of deciduous forests in northern Germany (Schleswig-Holstein). Forest Ecol Manag 182(13):327-338

Hejcmanovā-Nežerková P, Hejcman M (2006) A canonical correspondence analysis (CCA) of the vegetation-environment relationships in Sudanese savannah, Senegal. S Afr J Bot 72(2):256-262

Hou W, Walz U (2016) An integrated approach for landscape contrast analysis with particular consideration of small habitats and ecotones. Nat Conserv 14:25

Juarez A, Ortega-Baes P, Suhring S, Martin W, Galindez G (2007) Spatial patterns of dicot diversity in Argentina. Biodivers Conserv 16:1669-1677

Kazakis GGD, Vogiatzakis IN, Papanastasis VP (2007) Vascular plant diversity and climate change in the alpine zone of the Lefka Ori Crete. Biodivers Conserv 16:1603-1615

Koleff P, Gaston KJ, Lennon JJ (2003) Measuring beta diversity for presenceabsence data. J Anim Ecol 72:367-382

Kumar A (1987) Phytodiveristy and productivity studies on Bhadarwah Forests. PhD Thesis, University of Jammu, Jammu, India

Kumar V, Sharma A, Bhardwaj R, Thukral AK (2017) Phytosociology and Landsat TM data: a case study from river Beas bed, Punjab, India. 38th Asian Conference on Remote Sensing (ACRS, 23-27 October 2017)

Kumar V, Sharma A, Bhardwaj R, Thukral AK (2018) Comparison of different reflectance indices for vegetation analysis using Landsat-TM data. Rem Sens Appl Soc Environ 12:70-77

Maren IE, Karki S, Prajapati C, Yadav RK, Shrestha B (2015) Facing north or south: does slope aspect impact forest stand characteristics and soil properties in a semiarid trans-Himalayan Valley. J Arid Environ 121:112-123

Mehrabi Z, Slade EM, Solis A, Mann DJ (2014) The importance of microhabitat for biodiversity sampling. PLoS One 9(12):e114015

Mena J, Domı́nguez V (2005) Species turnover on elevational gradients in small rodents. Glob Ecol Biogeogr 14:539-547

Mohd-Aizat A, Mohamad-Roslan MK, Sulaiman WN, Karam DS (2014) The relationship between soil $\mathrm{pH}$ and selected soil properties in 48 years loggedover forest. Int J Environ Sci 4(6):1129

Murray DF (1997) Regional and local vascular plant diversity in the Arctic. Opera Bot 132:9-18

Nevo E (2001) Evolution of genome-phenome diversity under environmental stress. Proc Natl Acad Sci 98:6233-6240

Nowak A, Nowak S, Nobis M, Nobis A (2014) Vegetation of solid rock faces and fissures of the alpine and subnival zone in the Pamir Alai Mountains (Tajikistan, Middle Asia). Phytocoenologia 44(1-2):81-104

Odland A, Birks HJB (1999) The altitudinal gradient of vascular plant richness in Aurland western Norway. Ecography 22:548-566

Pandita S, Dutt HC (2016) Thermocline signaling ecotone-a thrust area for climate change research. Amer Inter J Res Form Appl Natur Sci 151:53-59

Paudel S, Vetaas OR (2014) Effects of topography and land use on woody plant species composition and beta diversity in an arid trans-Himalayan landscape, Nepal. J Mount Sci 11(5):1112-1122

Polunin O, Stainton A (1984) Flowers of the Himalaya. Oxford University Press, New Delhi

Pook E, Moore C (1966) The influence of aspect on the composition and structure of dry sclerophyll forest on black mountain Canberra, ACT. Aust J Bot 14:223-242 
Ries L, Fletcher RJ Jr, Battin J, Sisk TD (2004) Ecological responses to habitat edges: mechanisms models and variability explained. Annu Rev Ecol Syst 35: $491-522$

Schickhoff $U$ (2005) The upper timberline in the Himalayas Hindu Kush and Karakorum: a review of geographical and ecological aspects, mountain ecosystems. In: Broll G, Keplin B (eds) Studies in Treeline Ecology. Springer, Berlin, pp 275-354

Schickhoff U, Bobrowski M, Bohner J, Burzle B, Chaudhary RP, Gerlitz L, Heyken H, Lange J, Muller M, Scholten T, Schwab N, Wedegartner (2015) Do Himalayan treelines respond to recent climate change? An evaluation of sensitivity indicators. Earth Syst Dyn 6:245-265

Sharma BM, Kachroo P (1983) Flora of Jammu and plants of neighbourhood, vol I-II. Bishen Singh Mahendra Pal Singh, Dehradun India

Singh JS, Singh SP, Gupta SR (2010) Ecology environment and resource conservation. Anamya Publisher, New Delhi, p 641

Ucles O, Villagracia L, Canton Y, Lazaro R, Domingo F (2015) Non-rainfall water inputs are controlled by aspect in a semiarid ecosystem. J Arid Environ 113: 43-50

Wilson MV, Shmida A (1984) Measuring beta diversity with presence-absence data. J Ecol 72:1055-1064

Yarrow MM, Marin VH (2007) Towards conceptual cohesiveness: a historical analysis of the theory and utility of ecological boundaries and transition zones. Ecosystems 10:462-476

Zheng D, Zhang R, Yang Q (1981) Physic-geographic differentiation of the Qinghai-Tibetan Plateau. In: Zheng D (ed) Geological and ecological studies of Qinghai-Xizang Plateau. Science Press, Beijing, pp 1851-1860

\section{Publisher's Note}

Springer Nature remains neutral with regard to jurisdictional claims in published maps and institutional affiliations.

\section{Submit your manuscript to a SpringerOpen ${ }^{\circ}$ journal and benefit from:}

- Convenient online submission

- Rigorous peer review

- Open access: articles freely available online

- High visibility within the field

- Retaining the copyright to your article

Submit your next manuscript at $\boldsymbol{\nabla}$ springeropen.com 